\title{
オーステナイトステンレス熔着鋼の高温延性試験
}

\author{
鈴木 春義** 田村 博*** 小林 卓也***

\section{Hot Ductility Test of Austenitic Stainless Steel Weld Metals*} \\ By H. Suzuki**, H. Tamura*** and T. Kobayashi***
}

\begin{abstract}
Hot ductility, as revealed the values of reduction in area at the fracture surface tested at high temperatures on the weld thermal cycles, was studied on austenitic stainless steel weld metals by means of a reproducing apparatus of weld thermal cycles.

Five weld metals, including type $308 \mathrm{~L}, 347$ and 316 , were tested in this study. A round bar tensile specimen made from multiple pass weld, was heated rapidly up to the peak temperature of $1350^{\circ} \mathrm{C}$ and then broken at each temperature of $800,1000,1100,1200$ and $1300^{\circ} \mathrm{C}$ both on heating and cooling along the thermal cycle, respectively.

From the tests, hot ductility curves, expressed as percent reduction in area at fracture as a function of the testing temperatures were obtained for each weld metal.

From the values of reduction in area as measured both on heating and cooling at $1200^{\circ} \mathrm{C}$, hot ductility rating about these weld metals was determined as the following order.

On heating-308L [347(A), 347(B), 316] 347(C)

On cooling-308L [347(A), 347(B)] 316, 347(C)

Among the test weld metals, the hot ductility of type $308 \mathrm{~L}$ was the most superior, while that of type 347 (C) containing no ferrite was the poorest on the contrary.

Furthermore, the comparison was made between hot ductility and Fisco cracking test results for the test weld metals. A close relationship was found between the two, then the hot ductility was assured to be effective extensively as a measure of hot cracking susceptivility of austenitic stainless electrodes.
\end{abstract}

\section{1. 緒言}

最近我が国に括いても船舶や原子炉などの圧力容器の建 造に関連して,オーステナイトステンレス鋼の熔接に伴な う割れの問題が論議の対象となっている. 米国の Nippes らの研究 ${ }^{1,2}$ とよれば, オーステナイトステンレス鋼の熔 着金属あるいは熱影響部母材に起る高温割れは, 熔接熱サ イクル途中特に冷却中の高温で急速破断した試験片の断面 縮少率から求めた延性の低下と密接な関係があることが明 らかになり, 熱サイクル途中の各温度に括ける延性を調べ るいわゆる高温延性試験が最近米国で熔接棒の購入規格試 娩として使用されつつある.

筆者らは, 従来の熱サイクル再現装置 ${ }^{3}$ 飞熔接応力の再 現を加味した新装置を試作したが, 今回は本装置を利用し て数種の代表的なオーステナイトステンレス鋼の母材と熔 接棒を組合せた熔着金属の高温延性試験を行ない, 各熔着 金属の割れ感受性を比較検討した結果について報告する.

* 原稿受付, 昭和 34 年 6 月 26 日（昭和33年度熔接学会 秋季学術講演会に括いて発表）

** 正員, 金属材料技術研究所 Member, National Research Institute for Metals.

*** 正員, 運輸技術研究所 Member, Transportation Technical Research Institute

\section{2. 試 験 装 置}

筆者らが, 株式会社電元社に依頼して試作した試験装置 の外観を Fig. 1 抽よび Fig. 2 亿示す. Fig. 1 は Fig. 2 の（A）の部分を拡大して示したもので，(A) は引張試 験片（B）を支持する水冷電極，（C）は試験片を冷却す る $\mathrm{N}_{2}$ ガスを噴出するノズル，(D) 括よび（E）は，そ れぞれ温度 調節招よび 温度測定用 熱電対であ ๖. Fig. 2 は試験装置 の全景を示 したもの で, 右方の パネル (B) は試験片飞 流れる電流 の制御装置 で, 左方が 熔接変圧器 水冷電極招

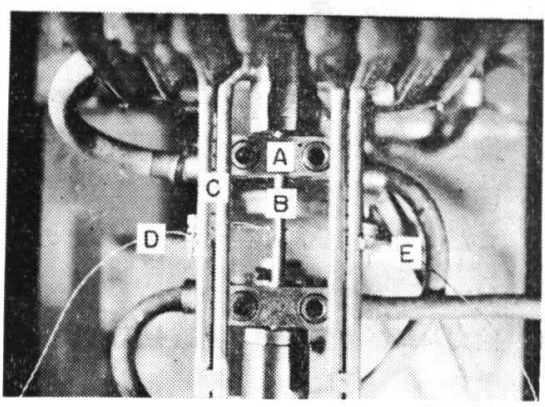

Fig. 1 Close-up of hot ductility test assembly

A-Electrode

B-Specimen

C-Spray

D-Thermo-couple for temperature recording

E-Thermo-couple for temperature control 


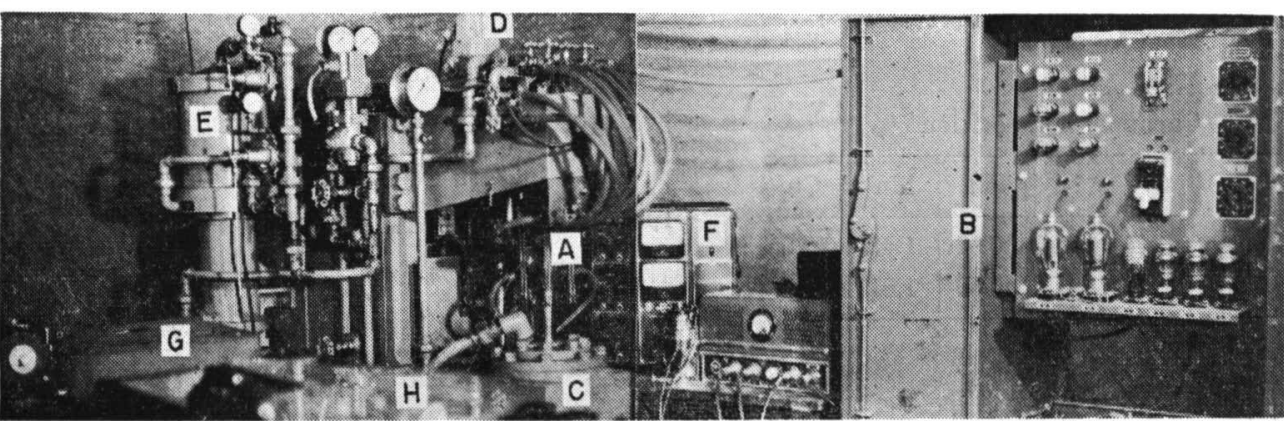

Fig. 2 Over-all view of hot ductility apparatus
E-Air-oil pressure cylinder (Booster)

$\mathrm{F}$-Dynamic strain meter

G-Electro-magnetic oscillograph

$\mathrm{H}-\mathrm{Cam}$ potentiometer

速破断の機構 㧈よび動作は 次の如くであ る. 試験片に 熱サイクルを 与えながら, その途中の所 定の試験温度 となると, カ ムポテショメ ーターに設置 したリミット スイッチが動 作して電磁空

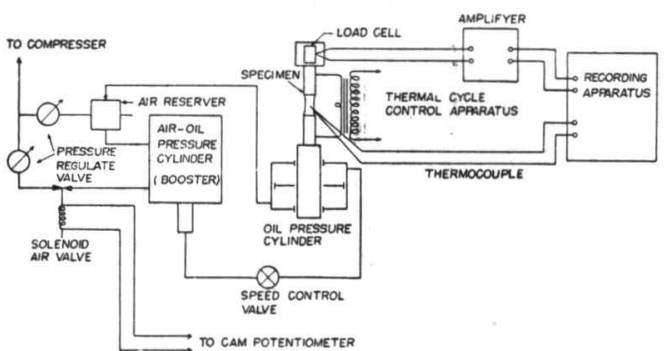

Fig. 3 Schematic diagram of hot ductility test apparatus

よび加圧機構を有する試験装置本体である.（C）は油 圧シリンダーで, そのピストンに試験片の下端が固定さ れる様になっている.（D）は電磁空気バルブ,（E）はブ ースター（空気油圧シリンダー）である. 本体と制御装置 の間はダイナミックストレインメータ（F）と電圧増巾 器, 本体の前方は電磁オッシログラフ ( $G$ ) およびカムポ テンショメータ（H）である. Fig. 3 は以上の装置の機 構を図解したもので, 本装置の熱サイクル再現の機構括よ び動作は従来の熱サイクル再現装置 ${ }^{3}$ と同様であるが, 急
気バルブを開き, 予めコンプレッサーで圧縮されていた圧 縮空気がブースターを介して試験片が固定されている油圧 シリンダーを急速に下方に押下けるととにより試験片は急 速破断される. 本装置の試験片飞加党得る最大応力は $5,000 \mathrm{~kg}$ で, 一定温度内で1/10秒以内に急速破断を行なう ことが出来る. 破断の際の応力は, 試験片の上端が固定さ れているロードセルをより, ダイナミックストレインメー タを介して電磁オッシログラフにより記録される.

\section{3. 試 験 方 法}

Fig. 4 亿試験片に与えた熱サイクル曲線を示す. この 熱サイクル曲線は, 板厚 $1 / 2$ 吋の 304 型ステンレス鋼板に, 308 型ステンレス熔接棒 (4 mm 径) で $32 \mathrm{~V}, 130 \mathrm{~A}, 150$ $\mathrm{mm} / \mathrm{min}$ の熔接条件でビード熔接を行なった場合の熱影 響部の温度分布から, 最高温度が, $1,350^{\circ} \mathrm{C}$ 飞相当する曲 線を求めたものである. 急速破断はこの熱サイクルの加熱 打よび冷却中, $800,1,000,1,100,1,200$ 打よび $1,300^{\circ} \mathrm{C}$ の各温度で行なった. 破断後, 試験片の破断面を投影器に より約20倍に拡大し, その像をセクションペーパーに複写

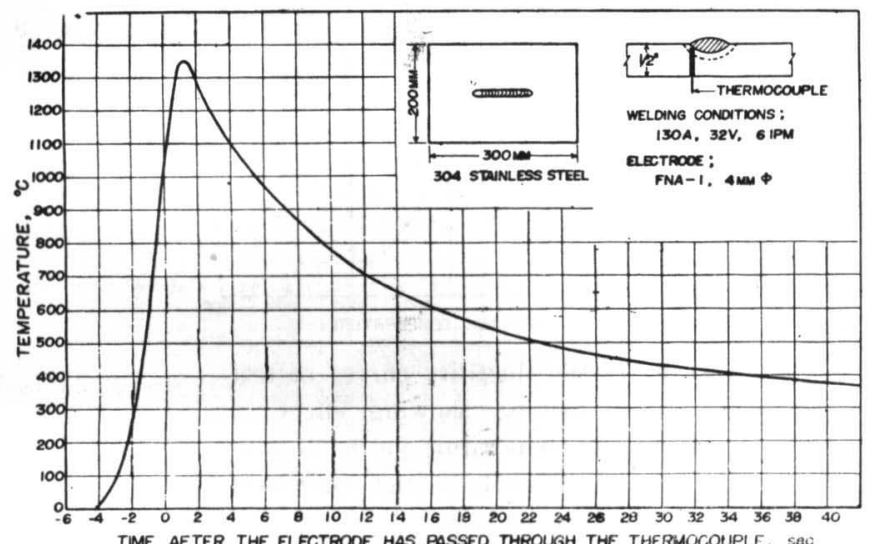

Fig. 4 Thermal cycle used for hot ductility test
して面積を測定し, 断面縮少率を計算して各種熔 着鋼についてその值を比較検討した. さらと代表 的な試験片について, 破断後の試験片の長軸方向 の縦断面に招ける熔着鋼のミクロ組織を検査し, 高温延性試験結果と比較検討した.

\section{4. 試験材および試験片}

使用母材は, オーステナイト系の 347 型ステン レス鋼と 304L 型ステンレス鋼の 2 種の圧延鋼材

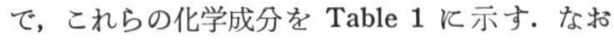
使用母材の寸法は 347 型が $500 \times 200 \times 12 \mathrm{~mm}$, $304 \mathrm{~L}$ 型は $300 \times 200 \times 12 \mathrm{~mm}$ であった.

これらの母材から Fig. 5 に示す様なU型突合 
Table 1 Chemical Compositions of Test Base Metals

\begin{tabular}{c|c|c|c|c|c|c}
\hline \hline \multirow{2}{*}{$\begin{array}{c}\text { Base metal } \\
\text { type }\end{array}$} & \multicolumn{5}{|c|}{ Chemical composition (\%)* } \\
\cline { 2 - 7 } & $\mathrm{C}$ & $\mathrm{Cr}$ & $\mathrm{Ni}$ & $\mathrm{Si}$ & $\mathrm{Mn}$ & $\mathrm{Cb}$ \\
\hline 347 & 0.05 & 18.44 & 10.88 & 0.57 & 1.43 & 0.70 \\
$304 \mathrm{~L}$ & 0.03 & 19.16 & 11.13 & 0.60 & 1.51 & - \\
\hline
\end{tabular}

* Check analysis
急速破断した試験片の断面縮少率を，各試験温度について プロットレ，各焀着銅別にまとめたすのである．加熱中の 試験飞招いては，各熔着龬共，その断面縮少率山最初試験 温度の上昇と共に徐々に増加して行くが; 試驗温度が 1,100 〜 1,200 $\mathrm{C}$ 以上になると急激減小する. この傾向はどの

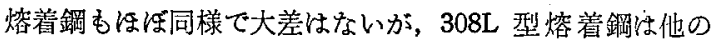
供試各噡着鋼に比して断面縮少率が減少し始める温度がや や高くまた $347 \mathrm{C}$ 型熔着鋼はその温度がやや低い様であ

Table 2 Chemical Compositions of Test Weld Metals 万左一方冷却

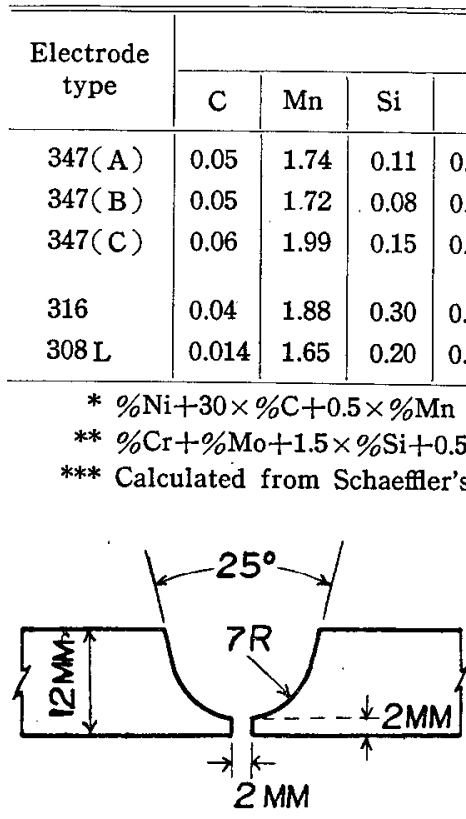

Fig. 5 Joint geometry of test plate prior to welding

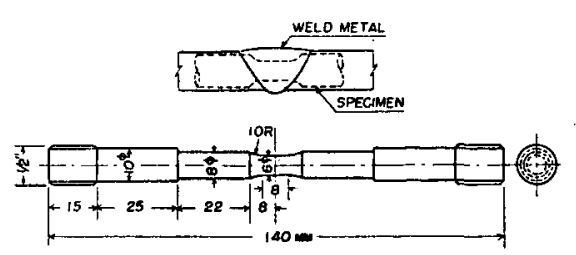

Fig. 6 Hot ductility test specimen
せ継手を作り, 347 型母材は 347 型棒 3 種 ( $\mathrm{A}, \mathrm{B}$ 和上 びC），㣘よび 316 型棒と 304L 型母 材は $308 \mathrm{~L}$ 型棒と 組合せ七，手塔接 により, $32 \mathrm{~V}, 130$ A, $150 \mathrm{~mm} / \mathrm{min}$ の熔接条 件で, 5 $\sim 7$ 層熔 接した. Table 2 にこれら の熔着鐝 の化学成分を示す.な炇接棒径はいつれも $4 \mathrm{~mm}$ を使 用した。

熔接を行なった試験材は X線透過写真を撮影して暙接部 に括ける欠陷の有無を検查したのち，熔着鋼が試験片の最

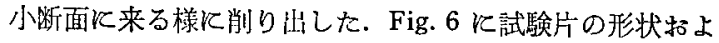
び切出し位置を示す。

\section{5. 高温延性試験結果}

Fig. 7 は, 熱サイクルの加熱拈よび冷却中の各温度で

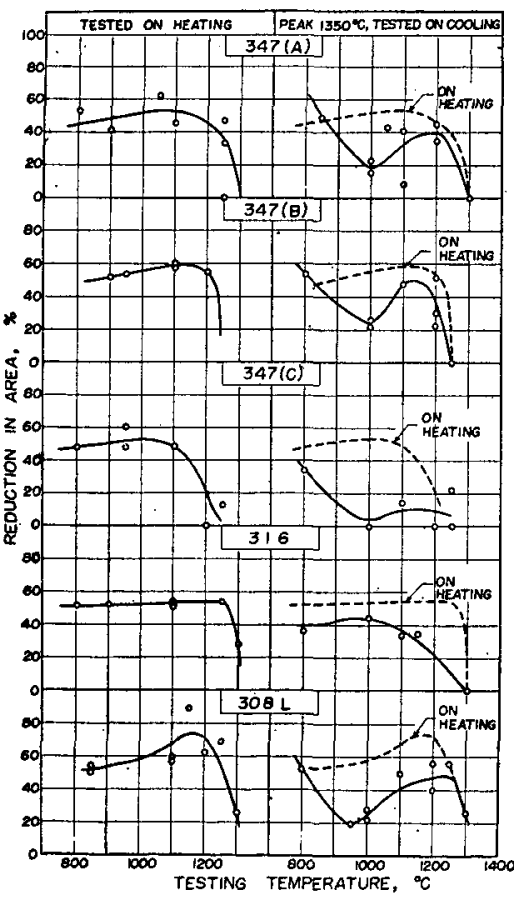

Fig. 7 Hot ductility curves of test weld metals, showing effect of testing temperature on the ductilities expressed as the values of reduction in area at the fracture surface
中の高温延性曲 線では，三種類 の347 型拓よび 308L 型燃着鋼 は结同様の傾 向を示し, 1,000 ${ }^{\circ} \mathrm{C}$ 附近で延性 が一時低下して いるが， 316 型 㝓着鋼にはこの 現象は見られな かった. Fig. 8 は，加熱拾 よび冷却中の $1,200^{\circ} \mathrm{C}$ で急 速破断した試 験片の断面宿 少率の平均值 によって各熔 着鋁の高温延 性を比較した ものである。 いま Fig, 8 の結果加 5 ， 各熔着鋼の高 温延性をその 良好なすの力 ら順次列へる 上次の様にな る。ただし括

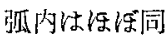
程度と見做し たものであ ๖. 
加熱中…308L, [347(A), 347(B), 316], 347(C)

冷却中 $\cdots 308 \mathrm{~L},[347(\mathrm{~A}), 347$ (B)], 316, 347(C)

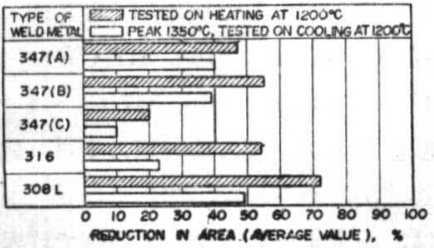

Fig. 8 Comparison of hot ductilities of test weld metals, tested on heating and cooling at $1200^{\circ} \mathrm{C}$

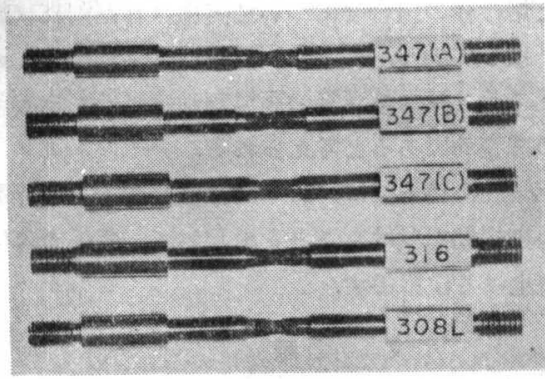

Fig. 9 Apperance of specimens tested on cooling at $1200^{\circ} \mathrm{C}$

$1,200^{\circ} \mathrm{C}$ で急速破断したのちの試験片の状態 を示したものである. Fig. 10 写真 a お よび b はそれらのうらの代表的な試験片 の破䉼面を示したものである、すなわちa は 308L 型熔着鋼（供試熔着鋼中高温延性が 最大）を $1,350^{\circ} \mathrm{C}$ から泠却中 $1,200^{\circ} \mathrm{C}$ で急 速破断した破断面を，また b は同じ試験 条件で急速破断した 347 型（C）熔着鋼（供 試熔着鋼中高温延性が最小）の破断面を示し たものである、a は破断面が絞りの大きい fibrous fracture を呈し, 延性がきわめて良 好であるが，一方 b 破面は全く断面収縮の 見られぬ特徵のある層状破面を呈し延性にき わめてそしかったことを示している.
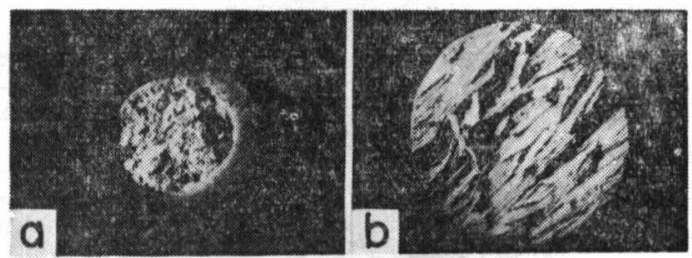

Fig. 10 Fracture surface of typical specimens tested on cooling at $1200^{\circ} \mathrm{C}$

$(\times 5)$

a) Type $308 \mathrm{~L}($ R.A. $=60 \%$ )

b) Type 347 (C) (R.A. $=0 \%$ )
6. ミクロ組織による考察

Fig. 11 写真 $a, b, c, d$ および e は, 供武各熔着 鋼を $1,350^{\circ} \mathrm{C}$ から冷却中 $1,200^{\circ} \mathrm{C}$ で急速破断した破断後 のミクロ組織を示したものである. 347型 (A), 347型 (B), 316型括よび $308 \mathrm{~L}$ 型各熔着鋼のミクロ組織はオー ステナイトナフエライトであるが, 高温延性が供試各熔着 鋼中最小であった347型（C）熔着鋼のミクロ組織は完全 オーステナイトであった. この事は完全オーステナイト組 織のステンレス熔着鋼は高温割れ感受性が大きいという

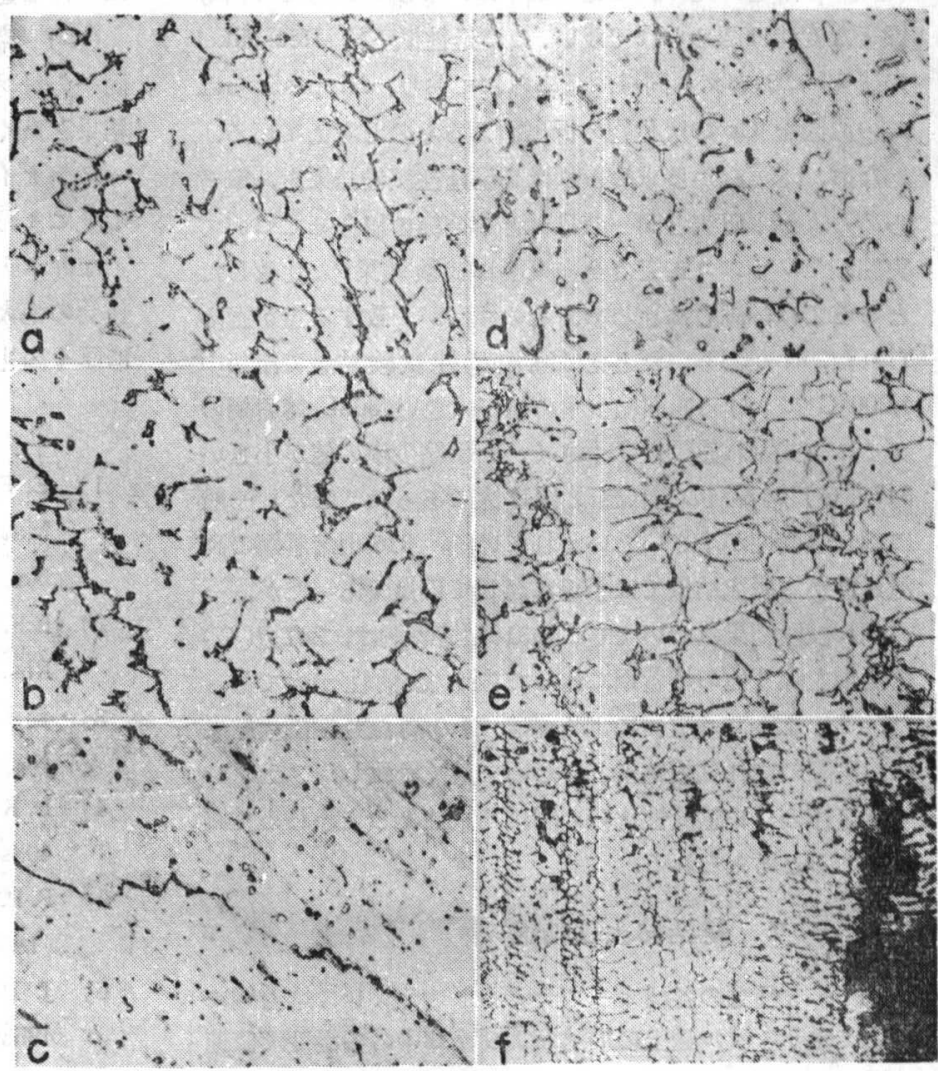

Fig. 11 Microstructures of test weld metals tested on cooling at $1200^{\circ} \mathrm{C}$

a) Type $347(\mathrm{~A})(\times 500)$ d ) Type $316(\times 500)$

b) Type $347($ B $)(\times 500)$ e $)$ Type $308 \mathrm{~L}(\times 500)$

c) Type $347(\mathrm{C})(\times 500)$ f) Type $347(\mathrm{~B})(\times 200)$

Poole の研究結果 ${ }^{4)}$ と良く一致している. また $\mathrm{Cb}$ を含有 する三種類の 347 型熔着鋼を, 冷却中急速破断したミクロ 組織には, オーステナイト結晶粒界に析出物が認められ た. 従来の研究によれば, オーステナイトステンレス鋼の 高温割れの有力な原因として低融点の粒界析出物の存在が 挙げらて括り, Puzak ${ }^{5}$ 等はこの析出物が少量の Mn, $\mathrm{Si}, \mathrm{Fe}$ を伴う $\mathrm{Cb}$ の炭化物と窒化物の共晶的化合物であ ることを確認している.な括，本実験結果でも $\mathrm{Cb}$ を含ま ない308L 型や316熔着鋼を冷却中破断した破断後のミク 
口組織には，この梯な粒界析出物は全く認められなかった ことからも本研究で兒られた析出物むこの種のものである 弓と推定される. Fig. 11 写僮 $\mathrm{f}$ は泠却中 $1,200^{\circ} \mathrm{C}$ で破 断した347型 (B) 焙着鋼の破断部附近のミクロ組繊を示 したものて破断が結昷粒界に沼って生じていることが判 る.また，供試各熔着鋼中もっとも高温延性が大であった 308L 型熔着鋼は，他の熔着鐝に比して結晶粒が微細であ ったととも高温延性が著しく良好であった原因の一つと思 われる.三種類の 347 型括よび 308L 型熔着鋼の泠却中 $1,000^{\circ} \mathrm{C}$ 附近見られた延性低下は, ミク口組織では何等 顕著な変化は認められてない.との延性低下は Heuschkel

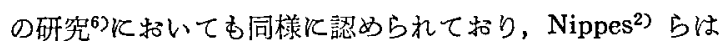
この原因を $\mathrm{Cr}$ の炭化物の析出に上るものと考元ている.

な拎，本実験から求められた高温延性試験結果安，筆者 らの一人が本研究と同一の母材と焀接棒の組合せ飞ついて 実施したフイスコ式突合せ拘束割れ試験結果7)と比較した よころでは，両者はきわめてその傾向が一致する点が認め られた。すなわち，たと党ば高温延性試験結果で泠却中 $1,200^{\circ} \mathrm{C}$ 飞和ける断面縮少率の值が大きい308L 熔着鋼の フイスコ式割れ感受性は小さく，断面縮少率の值が小さい 347 （C）熔着堸の割狆感受性は大であった。 また，一般 飞割れ感受性が小さいといわれている，316 型塔着鋼の高 温延性が本研究結果ては予想に反して不良であったが，一 方割れ試験結果に括いてもこの316型塔着鋼は，347型(C) 熔着鋼を除く他の熔着鍓飞比して割れ感受性が大であっ た.このように本実験による熔着鋼の高温延性試験結果 は，実際の割れ試験結果ときわめて良く一致し，ステンレ ス熔接棒のワレ感受性比較の間接的試験としてきわめて有 効であると考えられる.

\section{7. 総括およひ結論}

（1） 5 種類の各種オーステナイトステンレス揢着鍶に ついて熱サイクル途上の加熱扣よび泠却中の各温度で急速 破断するいわゆる高温延性試験を行ない，温度と断面縮少 率の関係を表わ亦高温延性曲線を求めてその破断面や組織 なととともにとの高温延性を比較することができた。
(2) $1,200^{\circ} \mathrm{C}$ に洛いて破断した加熱中括よび泠却中の

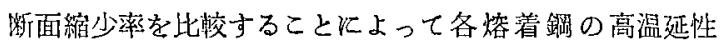
をそその良好なるのの順化列記すると次の如くなる.

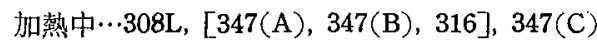

冷却中…308L, [347(A), 347(B)] 316, 347(C)

(3) 高温延性試験結果之試験後の熔着鋼のミク口組織 の間には明らかに関連性が認められた。

すなわち，たとえぼ，完全オーステナイト組織で粒界析 出物の認められた 347 型 (C) 熔着鋼は, 冷却中 $1,200^{\circ} \mathrm{C}$ に括ける延性が注とんど0\%であった。

(4)泠却中 $1,200^{\circ} \mathrm{C}$ 亿打行る高温延性試験結果沐, 同一の母材と謍接棒の組合せについて实施された割れ試験 結果と良く一致している. 從って高温延性試験結果は，才 一ステナイトステンレス签着鋼の高温制れ感受性を比洨す る上飞きわめて有効であると考方られる.

な牥本研究実施に当っては，日本熔接協会原子力研究委 員会の絶大な御援助を受けたことを附記して，関係者各位 に厚く御礼申上げる次第です.

\section{文献}

1) E. F. Nippes, W. F. Savage, B. J. Bastian, H. F. Mason and R.M. Curran, Weld. JI., Vol. 34 (1955), No. $4,183 \mathrm{~s} \sim 196 \mathrm{~s}$

2) E.F. Nippes, W.F. Savage and G: Grotke, Weld. Res. Council Bulletin Series, No. 33, Feb. (1957)

3）跉木, 田村, 川名，橋口，熔接学会誌，Vol. 26 (1957), No. 2, 68〜76.

4) L. K. Poole, Weld. JI., Vol. 32 (1953), No. 8, $403 \mathrm{~s} \sim 412 \mathrm{~s}$

5) P. P. Puzak and H. Rischall, Weld. JI., Vol. 36 (1957), No. 2, 57s $61 \mathrm{~s}$

6) J. Heuschkel, Weld. JI., Vol. 34 (1955), No. 10, $485 \mathrm{~s} \sim 504 \mathrm{~s}$

7）鈴木，日本熔接協会原子力委員会膭和 32 年度研究報 솜 